\title{
High-efficiency operation of supersonic COIL using nitrogen as buffer gas for optical power system
}

\section{光カシステムにおける窒素を用いた高効率超音速化学酸素沃素レーザー}

\author{
Masataka KAWAKAMI,Shoji NAGATOMO,Keiichi UMEHARA,Masamori ENDO and Shuzaburo TAKEDA \\ Department of Electro-Photo-Optics,Faculty of Engeineering,Tokai University, \\ 1117 Kitakaname,Hiratuka,Kanagawa 259-12 JAPAN \\ TEL:81-463-58-1211(EX.4431),FAX:81-463-58-7187 \\ Katsuhiko SUNAKO and TOMOO FUJIOKA \\ Department of Physics,School of Science,Tokai University, \\ 1117 Kitakaname,Hiratuka,Kanagawa 259-12 JAPAN \\ TEL:81-463-58-1211(EX.3700),FAX:81-463-50-2013 \\ Fumio WANI \\ Opto Engineering Depertment, Kanto Technical Institute, \\ Kawasaki Heavy Industries, 118 Futatuzuka,Noda,Chiba 278 JAPAN \\ TEL:81-471-24-0269,FAX: 81-471-24-5917 \\ ( Accepted for publication 6 November 1997 ) \\ The Chemical Oxygen lodine Laser(COIL) has unique characteristics and it is expected to be used in the energy \\ field. Usually, Lasing threshold of COIL is decreased by the supersonic expansion. To obtain the high stagnation \\ pressure at the plenum, helium is added as a buffer gas. However, using large amount of expensive helium is \\ out of the question for industrial applications. We achieved a high efficiency operation of COIL using nitrogen \\ as buffer gas. Obtained overall efficiency was $23.5 \%$ and it is the highest among the supersonic COILS using \\ nitrogen gas a buffer gas.
}

keywords : COIL, Supersonic expansion, $\mathrm{N}_{2}$ buffer gas, efficincy, Optical power system

\section{I.INTRODUCTION}

光技術は、情報産業、製造業において中核の技術の一つに なりつつある。この光技術に基づく新しいエネルギーシステ ムとして「光力システム」への期待が高まっている。光力シ ステムとは既存の電力システムに刘応するだけではなく、か つ補完するものであり、不英ファイバーで遠く離れたて場や 行家庭までりォトンを送光し受光端で種々の用途に利用でき るエネルギーシステムである。この光源として考えられる化 学酸素沃素レーザー（COIL: Chemical Oxygen Iodine Laser） は、諸特性よりエネルギー分野での利用が期待される斬続発 振レーザーである。'従来のCOILは、超音速ノズルによる断熟 㰣張を用い、レーザー媒質の温度を低下させ、発振の䦨值を 減少させている。そのため、超音速ノズル人币においてガス

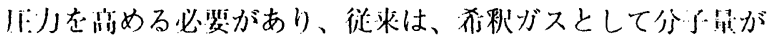
小さく此熱の大きいヘりりムが用いられていた。本砄究は、

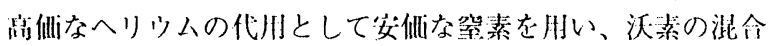
条作（沃素舅、キャリアガス量）簿の動作条作を最適化する ことによってへリウムと同等の化学效率を得ることを目似と

\section{して行った。}

\section{II .EXPERIMENTAL}

COILは、化学反㐫により生成した $\left.\mathrm{O}_{2}{ }^{1} \Delta\right)$ とI 光スを混合亦 るだけで発振する純化学レーザーである。

以下にレーザーの動作反忘式を示す。

$$
\begin{aligned}
& \left.\mathrm{H}_{2} \mathrm{O}_{2}+2 \mathrm{KOH}+\mathrm{Cl}_{2} \rightarrow \mathrm{O}_{2}{ }^{2}{ }^{2} \Delta\right)+2 \mathrm{H}_{2} \mathrm{O}+\mathrm{KCl} \cdots(1) \\
& \left.\left.\mathrm{I}_{2}+\mathrm{nO}_{2}\left({ }^{1} \Delta\right) \rightarrow 2 \mathrm{I}^{2}{ }^{2} \mathrm{P}_{3,3}\right)^{2}\right)+\mathrm{nO}_{2}\left({ }^{3} \mathrm{\Sigma}\right) \quad \cdots \cdot(2)
\end{aligned}
$$

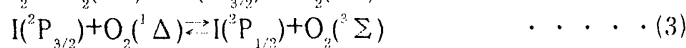

$$
\begin{aligned}
& \mathrm{I}\left({ }^{3} \mathrm{P}^{3 / 2}\right) \rightarrow \mathrm{I}\left({ }^{2} \mathrm{P}_{3,0}\right)+\mathrm{h} \nu(1.315 \mu \mathrm{m}) \quad \ldots . \cdot(1)
\end{aligned}
$$

(3)式のエネルギー移乘反忘の順反心速度定数Kfと近反忍速度 笔数Kr.は

$$
\begin{array}{lll}
\mathrm{Kf}=2.33 \times 10^{8} / \mathrm{T} & \cdots & \cdot(5) \\
\mathrm{Kr}=3.1 \times 10^{8} \exp (-403 / \mathrm{T}) / \mathrm{T} & \cdots & \cdot(6)
\end{array}
$$

で与えられる。ここで、Tは温度 [K] である。この反心は

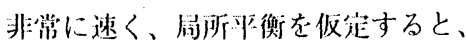

$\mathrm{Kf}\left[\mathrm{O}_{2}\left({ }^{1} \Delta\right) \|\left[{ }^{2}{ }^{2} \mathrm{P}_{3,2}\right)\right]=\mathrm{Kr}\left[\mathrm{O}_{2}\left({ }^{3} \Sigma\right) \| \mathrm{I}\left({ }^{3} \mathrm{P}_{1,2}\right)\right] \quad \cdots \cdot(7)$ となる。この式にKf、Krを代人することにより

$\left.I\left[\left({ }^{2} \mathrm{P}_{1 / 2}\right)\right] /\left[1\left({ }^{2} \mathrm{P}_{3 / 2}\right)\right]=0.75 \exp (403 / \mathrm{T})\left[\mathrm{O}_{2}\left({ }^{\prime} \Delta\right)\right] /\left[\mathrm{O}_{2}{ }^{2} \Sigma\right)\right] \cdot \cdots(8)$

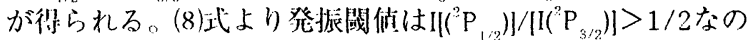

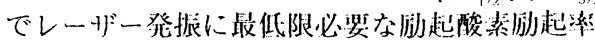

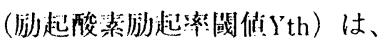

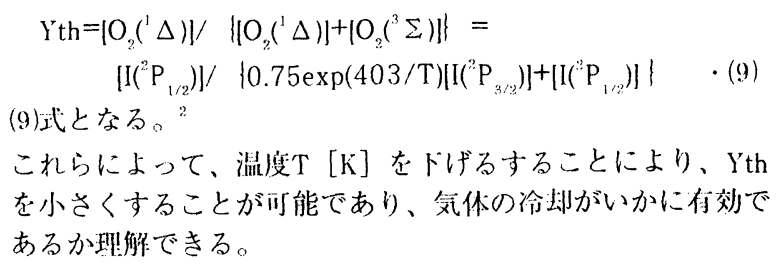




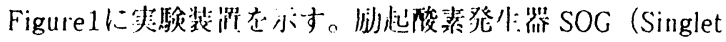
Oxygen Generator）より生成された $\left.\mathrm{O}_{2}{ }^{\prime} \Delta\right)$ は杀秋げスであ る虽素のバッファガスと混命され、更にキャリアブスであ る窑素により沃素分子が倛給され、超音速ノズルにおいて 断熱彫張を起こし発振する。今四の実験では、バッファ ガス及びキャリアガスを変化させ、またあらかじめ彾却 したバッファオ゙スを流し込むことにより絬果を検討した。

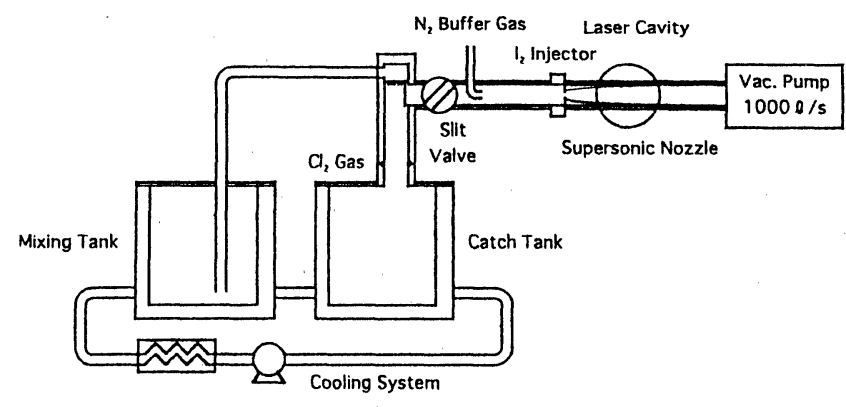

FIG.1. Experimental Device.

\section{III.RESULTS}

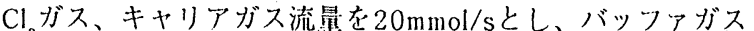
流暈を変化させた時の川小変化の絬果をFig.2に示す。

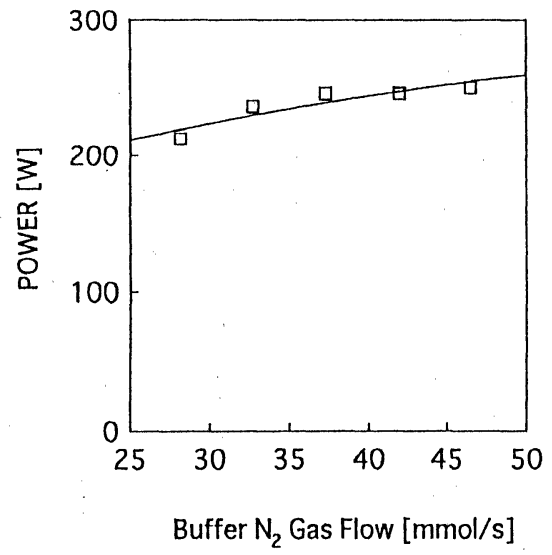

FIG.2. Relationship between laser power and buffer gas flow.

バッファガスの增㸪伴い断熱膨張效果を增大寸ることで

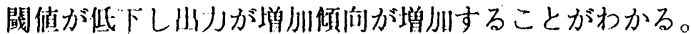

次にバッファブス及びキャリアガスの登素の流量を令計 $60 \mathrm{mmol} / \mathrm{s}$ とし、バッファグス流量を変化させたときの山う 変化をFig.3に示す。

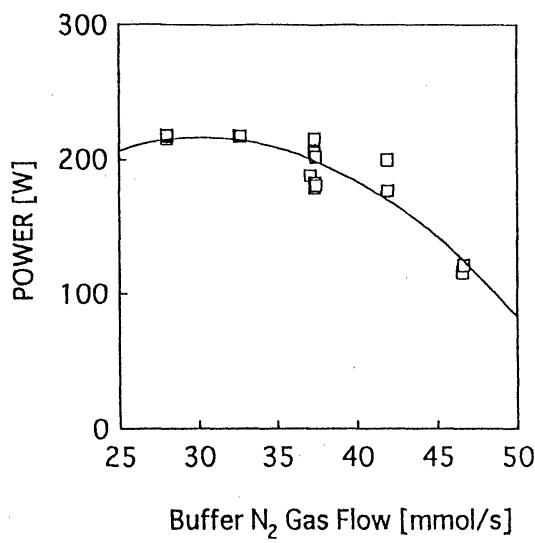

FIG.3. Relationship between laser power and buffer gas fiow (N, Total flow $60 \mathrm{mmol} / \mathrm{s})$.

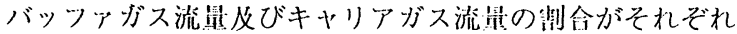

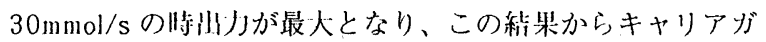
スによって优給される沃素量の変化に伴い、沃箱量が過剩な とき近に不迡なときは、玔が低下することがわかる。

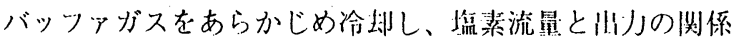
老Fig.4に亦す。

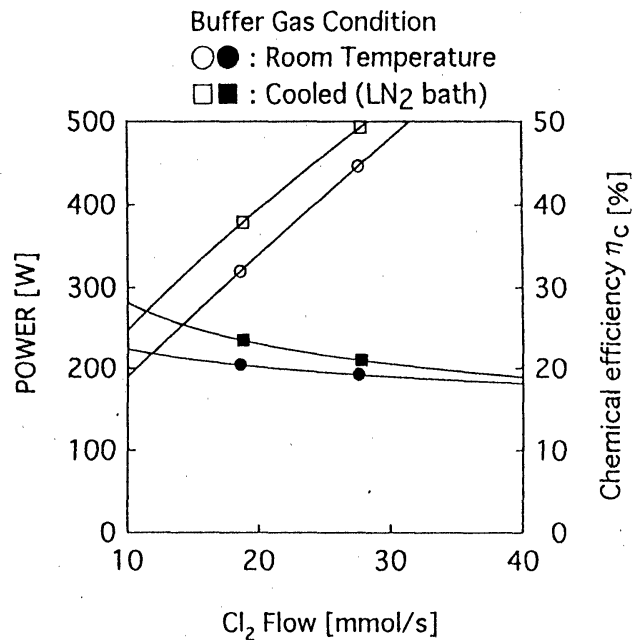

FIG.4. Relationship betweenlaser power and $\mathrm{Cl}_{2}$ flow.

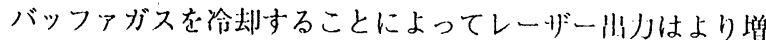

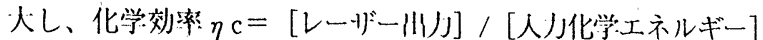

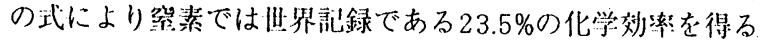
乎ができた。

\section{REFERENCES}

${ }^{1}$ Hiroo Fujii, Hiroshi Tuji, Mikio Muro, Fumio Wani, Noriyuki Naito, Touru Nagai, Kouzou Yasuda, Takatoshi Shouuji, Kawasaki technical review, vol.131, 204-209 (1996)

${ }^{2}$ P.V.Avizonis, K.A.Truesdell, SPIE, vol.2502, 180-203 (1994)

'97 SAS Intelligent Symposium 